
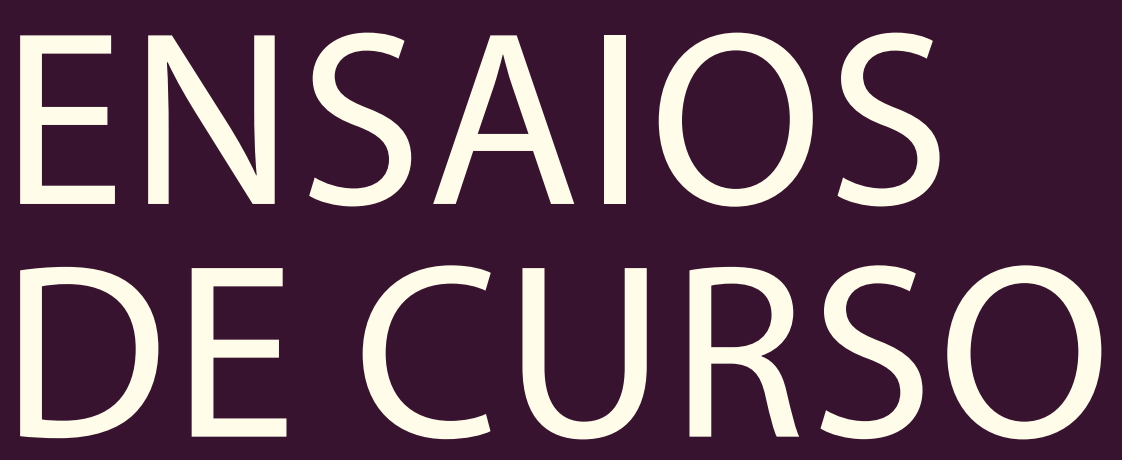



\title{
A CRISE DO ROMANCE SEGUNDO OS ENSAIOS E O CONTO "AN UNWRITTEN NOVEL" DE VIRGINIA WOOLF
}

\author{
- JOSÉ PEREIRA DE QUEIROZ
}

\section{RESUMO}

Este artigo analisa o conto "An unwritten novel", de Virginia Woolf, à luz da discussão proposta pela própria autora em diversos de seus ensaios acerca das dificuldades e das possibilidades encontradas por seus contemporâneos em relação à escrita de ficção. $O$ que define o gênero romance, para a autora, é uma preocupação com a apreensão e a representação de algo por ela denominado como character, que é tanto uma personagem na obra quanto um traço fundamental da experiência humana materializado em um indivíduo real e percebido por um escritor. Em relação à própria geração, Woolf identifica a necessidade de rompimento com as convenções então vigentes do romance para que a forma possa, uma vez mais, estabelecer essa aproximação entre escritor, mundo e leitor centrada na representação do character. O conto analisado aprofunda essa discussão não necessariamente em seus temas, mas principalmente na instabilidade formal de seu narrador.

Palavras-chave: Virginia Woolf; Romance; Conto; Ensaio; Character.

\section{ABSTRACT}

This article analyzes Virginia Woolf's short story "An unwritten novel" in view of the discussion proposed by the author in several of her essays regarding the difficulties and the possibilities faced by her contemporaries when writing fiction. What defines the novel, for Woolf, is the attempt to apprehend and represent a character, a term which stands for both a fictional device in the story and for a distinctive aspect of human experience materialized in a real individual and perceived by a novelist. Woolf identifies the need of her own generation of writers to break with the then established novel conventions to, once again, from the representation of a character, reapproximate the novelist, the world, and the reader. The analyzed short story furthers this discussion not through its themes, but in the formal instability of its narrator.

Keywords: Virginia Woolf; Novel; Short story; Essay; Character. 
$\mathrm{O}$ conto "An unwritten novel" (Woolf, 1989) declara abertamente em seu título tratar da (não) escrita de um romance. Curiosamente, talvez seja um tanto impreciso dizer que o restante do conto também trate "abertamente" da escrita de um romance, já que, exceto pelo título, não existem outras menções ao gênero romance ou mesmo ao ato da escrita. Seu enredo, por outro lado, nos impele a examinar esse conto à luz de um debate proposto por Woolf em outros de seus textos, uma vez que sua premissa básica é a mesma usada para exemplificar a questão fundamental no ensaio "Character in fiction" (Woolf, 2008a): um encontro fortuito em um vagão de um trem com uma mulher mais velha que impressiona fortemente a pessoa que a observa; a atribuição de um nome a essa mulher; o sentimento de sofrimento e de dor percebido na figura dela; e a necessidade de se tentar apreender e narrar sua história a partir da impressão e das sensações causadas pelo encontro. No ensaio, Woolf usa essa história para apresentar um episódio supostamente verídico que exemplifica o nascimento de um romance na mente do escritor. Podemos perceber, assim, que mesmo sem mencionar o processo de escrita em si, por seu título e pela proximidade com esse ensaio, o conto está trabalhando com os elementos da elaboração e composição de um romance. Para compreendermos, então, de que maneira aquilo que é apresentado no conto pode de fato ser "um romance não escrito", é necessário que observemos como o gênero romance e a escrita ficcional como um todo são abordados por Woolf em seus ensaios.

Partindo dessa premissa comum aos dois textos - um encontro fortuito num trem com uma mulher mais velha que causa no narrador uma forte impressão -, em "Character in fiction", Woolf (2008a) identifica a centralidade daquilo que ela chama de character para a forma do romance e para a representação narrativa. Characteré uma palavra de difícil tradução, podendo significar tanto personagem quanto personalidade, ou até mesmo caráter, entre outros sentidos ${ }^{1}$. Além disso, nesse ensaio o termo é usado de maneira bastante específica, mesmo que pareça, segundo a própria autora, um tanto vago ao leitor; em outras palavras, por mais que o conceito seja central para a forma romance como Woolf a entende, é difícil defini-lo diretamente.

Dessa maneira, o episódio do encontro mencionado acima tenta explicar indiretamente, por meio de um exemplo, o que ela quer dizer quando utiliza o termo e, ao mesmo tempo, demonstra como, para Woolf, todo romance nasce do interesse do escritor em apreender e representar determinado character:

Most novelists have the same experience. Some Brown, Smith, or Jones comes before them and says in the most seductive and charming way in the world, "Come and catch me if you can." [...] Men and women write novels because they are lured on to create some character which has thus imposed itself upon them. (idem, p. 37)
[1] Por essa razão, optamos por utilizar o termo em inglês. 
A história que Woolf conta no ensaio para exemplificar o sentido de character relata justamente uma experiência dessas. A desconhecida que ela encontra por acaso em um vagão de trem a atrai profundamente, e Woolf começa de imediato a imaginar a história dessa mulher: Ihe dá um nome, Mrs. Brown, e um filho; estabelece um conflito com o homem com quem conversa; imagina os sentidos e os sentimentos por trás de suas expressões corporais etc. Character, dessa maneira, parece assumir o sentido de personagem, e seu papel central num enredo, ou pelo menos na cena, parece ser o que define o interesse do escritor.

Mais importante do que narrar a história, interessa a Woolf mergulhar na atmosfera da personagem: "details could wait. The important thing was to realise her character, to steep oneself in her atmosphere" (idem, p. 42). Aqui, Woolf usa character em um sentido já um tanto diferente. Não mais a personagem em si, mas um aspecto fundamental da personagem que se torna acessível em decorrência da impressão arrebatadora que a mulher causa:

The impression she made was overwhelming. It came pouring out like a draught, like a smell of burning. What was it composed of-that overwhelming and peculiar impression? Myriads of irrelevant and incongruous ideas crowd into one's head on such occasions; one sees the person, one sees Mrs Brown, in the centre of all sorts of different scenes. (idem, p. 41)

Character surge, então, como uma espécie de estopim para essa impressão, estabelecendo um eixo central para uma miríade de ideias soltas, de cenas esparsas. Para além da mulher real que Woolf viu no trem, o character é Mrs. Brown, a personagem imaginada de definição difusa; é a forte impressão sentida; é a miríade de ideias e cenas que assaltam a mente de quem narra; é o fio condutor da construção de um romance:

Here is a character imposing itself upon another person. Here is Mrs Brown making someone begin almost automatically to write a novel about her. I believe that all novels begin with an old lady in the corner opposite. I believe that all novels, that is to say, deal with character, and that it is to express character-not to preach doctrines, sing songs, or celebrate the glories of the British Empire, that the form of the novel, so clumsy, verbose, and undramatic, so rich, elastic, and alive, has been evolved. (idem, p. 42)

A capacidade de expressar um characteré, portanto, o traço distintivo do romance enquanto gênero, para Woolf. 
Em outro ensaio, "Mr. Bennett and Mrs. Brown", Woolf (2008d) novamente argumenta que o propósito do romance é criar human character. Agora, em oposição ao ensaio anterior, a autora tenta explicar de maneira mais direta o que ela quer dizer com o termo character:

For what, after all is character - the way that Mrs Brown, for instance, reacts to her surroundings-when we cease to believe what we are told about her, and begin to search out her real meaning for ourselves? In the first place, her solidity disappears; her features crumble; the house in which she has lived so long (and a very substantial house it was) topples to the ground. She becomes a will-o'-the-wisp, a dancing light, an illumination gliding up the wall and out of the window, lighting now in freakish malice upon the nose of an archbishop, now in sudden splendour upon the mahogany of the wardrobe. The most solemn sights she turns to ridicule; the most ordinary she invests with beauty. She changes the shape, shifts the accent, of every scene in which she plays her part. (idem, p. 35)

Mais do que Mrs. Brown em si, importantes seriam suas reações ao mundo que a rodeia. Impossível de ser definida por seus atributos ou por sua casa, a personagem perde seus contornos sólidos, se torna mutável, é uma luz que ilumina ora elementos de seu entorno, ora relações com diferentes pessoas. Assim, o character seria, também, o ponto de partida para a caracterização do mundo a seu redor, e vice-versa. O mundo se torna visível apenas quando iluminado por essa personagem difusa, que, por sua vez, ganha contornos à medida que ilumina as coisas e pessoas a seu redor; ambos, personagem e mundo, só se tornam conhecidos quando refletidos um pelo outro.

Tendo em vista o que apresentamos até o momento, poderíamos considerar character unicamente como um elemento formal do romance, e nossa justificativa para não traduzirmos o termo para personagem pareceria um tanto vazia. Nesse sentido, a maior diferença, em relação a outras definições de personagem, estaria nessa forma difusa que Woolf Ihe atribui, nessa composição pelo registro de impressões diversas ao redor da personagem, nessa função mediadora desempenhada na figuração do mundo ao redor.

Por enquanto, o enfoque dado por Woolf à centralidade da personagem no romance não é necessariamente uma perspectiva nova sobre o gênero. Watt (1962) e Lukács (2009) também afirmam essa centralidade, identificando a ascensão do romance com a necessidade de estabelecimento de uma forma que dê conta de representar uma sociedade formada por indivíduos isolados. A diferença maior, até aqui, é que esses autores, ao investigarem o surgimento 
do romance, posicionam a personagem individual dentro de sistema formal que possui também outras peças fundamentais. Watt (1962), por exemplo, enxerga a individualização da personagem como parte de um processo maior de particularização dos diferentes aspectos da narrativa, enquanto Lukács (2009) defende que não é simplesmente uma personagem típica que serve de centro para o romance, mas a ação dessa personagem no mundo, uma vez que é pela ação que a personagem interage com a sociedade e que os conflitos sociais passam a poder ser representados. Para Woolf, o enfoque parece ser quase exclusivamente na personagem como eixo central do romance; todo o resto estaria a serviço do movimento de apreensão e figuração dela.

A questão é mais complexa se considerarmos outros usos do termo character nos dois ensaios mencionados. Em "Character in fiction", Woolf (2008a, p. 37) afirma que todas as pessoas naturalmente possuem a habilidade de julgar um character em suas vidas cotidianas - aqui, o termo seria mais bem traduzido como caráter, ou mesmo personalidade, e se refere a algo externo à literatura. Segundo a autora, essa habilidade de julgar o caráter ou a personalidade dos outros é absolutamente necessária para a vida prática, e nossas relações pessoais dependem dela. Em "Mr. Bennett and Mrs. Brown", character é visto como o aspecto mais interessante da vida real:

In real life there is nothing that interests us more than character, that stirs us to the same extremes of love and anger, or that leads to such incessant and laborious speculations about the values, the reasons, and the meaning of existence itself. To disagree about character is to differ in the depths of the being. It is to take different sides, to drift apart, to accept a purely formal intercourse forever. (Woolf, 2008d, p. 35)

O fato, segundo Woolf, de que todos nós somos necessariamente interessados pelo character é, portanto, visto como um traço humano fundamental. Além de essencial em nossa interação com outras pessoas, é esse interesse que guia nossas paixões, que nos faz questionar valores e a própria existência. Character, dessa forma, deve ser compreendido de maneira dupla: como um aspecto fundamental da experiência humana que guia nossas percepções uns dos outros - e, portanto, nossas relações - e como elemento formal da ficção, materializado, a princípio, na personagem. Caberia ao romance estabelecer a transposição do primeiro para o segundo.

Em um terceiro artigo, "Modern Fiction”, Woolf (2008c) não menciona a centralidade de character na composição do romance, utilizando, para um fim semelhante, o conceito de vida. O fundamental para o romance seria, então, apreender a vida, que, como o character dos outros ensaios, se apresenta 
como algo fugidio e de difícil definição. As semelhanças entre os dois conceitos são bastante claras: "Life is not a series of gig lamps symmetrically arranged; life is a luminous halo, a semi-transparent envelope surrounding us from the beginning of consciousness to the end." (idem, p. 9). Ambos recusam o detalhamento preciso de seus atributos, são comparados à luz e aproximados à consciência. Além disso, o modo como acessamos a vida também é por meio das impressões que ela nos causa:

The mind receives a myriad impressions - trivial, fantastic, evanescent, or engraved with the sharpness of steel. From all sides they come, an incessant shower of innumerable atoms; and as they fall, as they shape themselves into the life of Monday or Tuesday, the accent falls different from old. (idem, p. 9)

Nesse último ensaio, a autora ainda apresenta outros termos que, para ela, tentam exprimir o mesmo conceito de vida: espírito, verdade, o essencial e, para os críticos, realidade ${ }^{2}$ (idem, p. 8). Com esse último, podemos perceber que o problema central do romance para Woolf relaciona-se a uma noção de realismo presente no gênero. Ao romance, cabe representar a realidade de maneira que seja percebida como verdadeira tanto pelo leitor quanto pelo escritor. A escolha, nos demais ensaios, pelo termo characterevidencia que para Woolf é somente a partir da figuração de um sujeito específico, um indivíduo posicionado frente ao mundo, que se torna possível essa representação da vida.

O escritor encontra, no romance, um meio de representar a realidade profunda a partir da apreensão e elaboração de um indivíduo que permite iluminar o mundo a seu redor. A recorrência do uso de imagens associadas à luz, à consciência e a impressões assaltando a mente reforça essa ideia de que, para Woolf, o traço distintivo do romance é que nele o mundo só se torna acessível quando posto em relação a um indivíduo: "in all these novels all these great novelists have brought us to see whatever they wish us to see through some character. Otherwise, they would not be novelists; but poets, historians, or pamphleteers" (Woolf, 2008a, p. 43).

Novamente, podemos perceber que Woolf remete a noções a respeito do romance presentes desde os momentos do surgimento do gênero. Lukács (2009), por exemplo, defende que é somente a partir da figuração de um indivíduo típico em sua relação com a sociedade que o romance deixa de ser apenas uma crônica sobre a prosa da vida e pode alcançar a totalidade da representação de um mundo. Como vimos, para Lukács, é a partir da ação dessa personagem que o mundo se revela paulatinamente. Na sociedade burguesa, um herói não pode mais representar sua sociedade como um todo, mas pode ser típico de sua classe e, pelo conflito estabelecido com outras personagens
[2] Tentando explicar o termo vida e dificuldade em definir seu conceito, Woolf (2008c, p. 8) escreve: "it is a confession of vagueness to have to make use of such a figure as this, but we scarcely better the matter by speaking, as critics are prone to do, of reality. [...] Whether we call it life or spirit, truth or reality, this, the essential thing, has moved of, or on, and refuses to be contained any longer in such ill-fitting vestments as we provide". 
também típicas, a totalidade da luta de classes se torna apreensível. Apesar de se dedicarem a examinar épocas diferentes, tanto Woolf quanto Lukács consideram que a composição do romance é construída a partir das relações que se estabelecem entre a personagem central e outras personagens, entre a personagem central e o mundo. A maneira como Woolf vê essa relação é, no entanto, mais limitante. Se, para Lukács, os romances dos séculos XVIII e XIX buscam, a partir da centralidade da personagem típica, a representação da totalidade do mundo, para Woolf, no início do século XX, a totalidade do mundo talvez não seja apreensível. Pela escolha de imagens na caracterização tanto do character quanto da vida, percebemos que, por mais que o mundo só se torne visível quando iluminado por essas entidades, a visibilidade é no máximo parcial. São flashes de luz que revelam fragmentos do mundo, e são esses fragmentos do mundo que dão o contorno frágil da personagem.

Se o mundo só é visível, ainda que de maneira parcial e fragmentada, quando percebido em relação a um indivíduo, por outro lado, parece-nos que, para Woolf, o próprio indivíduo só se torna acessível quando posto em relação ao escritor. A autora afirma que a mesma Mrs. Brown pareceria diferente para autores de diferentes nacionalidades, idades e temperamentos:

old Mrs Brown's character will strike you very differently according to the age and country in which you happen to be born. [...] And then there is the writer's temperament to be considered. You see one thing in character, and I another. You say it means this, and I that. And when it comes to writing each makes a further selection on principles of his own. Thus Mrs Brown can be treated in an infinite variety of ways, according to the age, country, and temperament of the writer. (Woolf, 2008a, p. 42-43)

Para o leitor, parece haver duas relações que se espelham: a que existe entre o mundo e o indivíduo representado, ou character, e a que existe entre o character e o escritor. Durante a leitura de um romance, o mundo é acessível somente através dessas duas camadas de filtragem: um determinado character só pode iluminar certos aspectos do mundo; um determinado escritor, certos aspectos do character.

Dessa maneira, para Woolf, o problema formal no centro do romance é a tentativa de apreensão da vida por meio da elaboração de um character, conceito que deve ser compreendido em dois planos, como traço fundamental do ser humano empírico, o sujeito ou o indivíduo no mundo, e como forma literária, a princípio a personagem. A transposição de um plano para o outro, do mundo para a forma, é feita pelo escritor, dentro de suas próprias limitações frente à matéria. $\mathrm{O}$ modo de apreensão do mundo pela figura do character 
configura, portanto, a marca distintiva do gênero romance e, como veremos adiante, a crise do romance no início do século XX é fruto, segundo a autora, de uma marcada e inescapável mudança no "human character" (idem, p. 38).

Poderíamos atribuir essa centralidade que Woolf confere ao character no romance a um interesse particular da autora pela subjetividade individual do outro. Esse interesse extrapola o campo do romance e é visível quando a autora discute outros gêneros, como o ensaio. Em "The decay of essay-writing" (2008e, p. 3), Woolf afirma que, no campo da escrita, uma das poucas invenções modernas de valor inquestionável é o ensaio pessoal ("personal essay"). Para Woolf, o ensaio é uma forma essencialmente egotista ${ }^{3}$, preocupada principalmente com o próprio eu do escritor, e é por isso que ele possuiria valor: "if they would write of themselves_such writing would have its own permanent value" (idem, p. 5). Esse valor decorre de o ensaio ser um meio ideal para expressão de opiniões pessoais, que interessariam, se por nenhuma outra razão, por possibilitar o acesso, para o leitor, à interioridade de um outro nesse caso, a do próprio escritor. Assim, o principal problema encontrado pelo ensaio, ainda segundo Woolf, seria a incapacidade de alguns escritores de se voltarem para suas interioridades e escreverem sobre elas com veracidade e sinceridade:

Confronted with the terrible spectre of themselves, the bravest are inclined to run away or shade their eyes. And thus, instead of the honest truth which we should all respect, we are given timid side-glances in the shape of essays, which, for the most part, fail in the cardinal virtue of sincerity. (idem, p. 5)

Como podemos ver, não é apenas no romance que interessa a Woolf encontrar a representação de uma individualidade. Todavia, existe uma diferença significativa no que a autora encontra nos dois gêneros. $O$ ensaio se configura como um meio propício à expressão da subjetividade do próprio escritor, que pode, então, ter uma parte sua, uma opinião ou uma perspectiva, transmitida ao leitor. $O$ romance é o gênero no qual o escritor encontra os meios e as ferramentas para representar um outro em sua totalidade e, a partir desse outro, representar o mundo. E é por essa razão que o character, em seu sentido duplo de elemento do mundo e da forma, possui uma posição central nesse gênero.

Para Woolf, há uma crise que abala o romance no início do século $X X$, relacionada diretamente com essa centralidade do character. A apreensão do character pela forma estaria se tornando cada vez mais difícil, e isso causaria uma série de rupturas internas ao gênero. Uma das evidências das mudanças na forma acarretadas por essa crise pode ser percebida, segundo Woolf, na
[3] "An essay is essentially egoistical" (Woolf, 2008e, p. 4). 
existência de certo antagonismo entre sua própria geração de escritores, chamados por ela de georgianos, e a anterior, denominados eduardianos. $\mathrm{O}$ ensaio "Mr. Bennett and Mrs. Brown" (Woolf, 2008d) começa com uma citação de Arnold Bennett, escritor eduardiano, em que ele afirma que na geração de Woolf não existem grandes romancistas. $O$ motivo do fracasso dessa geração, para o escritor, é a incapacidade de se criarem bons "individual characters" (idem, p. 32) que seriam o alicerce da boa ficção. É curioso notarmos como Woolf concorda com Bennett a respeito tanto da centralidade do characterno romance quanto da insuficiência dos romances de seu tempo, sobre os quais ela mesma pontua: "it is because this essence, this character-making power, has evaporated that novels are for the most part the soulless bodies we know, cumbering our tables and clogging our minds" (idem, p. 32). É na hora de encontrar os responsáveis por essa perda que ambos divergem. Se Bennett acusa os georgianos, Woolf afirma que é a era eduardiana que primeiro perdeu essa capacidade: "Surely that was the fatal age, the age which is just breaking off from our own, the age when character disappeared or was mysteriously engulfed" (idem, p. 32).

Woolf nos oferece, então, uma representação simplificada de como um romance eduardiano trabalha seus characters.

Every sort of town is represented, and innumerable institutions; we see factories, prisons, workhouses, law courts, Houses of Parliament; a general clamour, the voice of aspiration, indignation, effort and industry, rises from the whole; but in all this vast conglomeration of printed pages, in all this congeries of streets and houses, there is not a single man or woman whom we know. (idem, p. 33)

Para Woolf, essa geração valoriza lugares e instituições sociais em detrimento dos personagens; a estrutura em detrimento da experiência vivida; o geral em detrimento do individual. "The Edwardian novelists therefore give us a vast sense of things in general; but a very vague one of things in particular" (idem, p. 34).

Em outro ensaio, "Modern fiction" (Woolf, 2008c), os eduardianos são chamados de "materialistas", termo que a autora define das seguintes maneiras: "they are concerned not with the spirit but with the body" (idem, p. 7) e "we mean by it that they write of unimportant things; that they spend immense skill and immense industry making the trivial and the transitory appear the true and the enduring." (idem, p. 8). Woolf elogia a habilidade descritiva de Bennett e a empatia e a generosidade de Wells, mas afirma que em ambos falta o essencial, a vida escapa.

Com a melhor das intenções, os eduardianos se preocuparam com as 
injustiças sociais que Woolf admite não terem sido devidamente representadas pela geração anterior à deles, os vitorianos, que, por sua vez, ainda haviam sido capazes de representar seus characters de maneira bastante efetiva: "they love, they joke, they hunt, they marry; they lead us from hall to cottage, from field to slum. The whole country, the whole Society, is revealed to us, and revealed always in the same way, through the astonishing vividness and reality of the characters" (Woolf, 2008d, p. 33). No entanto, essa representação do mundo, que aparentava ser total, apagava uma série de relações sociais mais problemáticas que estavam na base da vida social percebida por meio dos characters. Woolf admite que, do ponto de vista dos eduardianos, parecia haver algo faltando por trás da abundância da vida dos personagens dos romances vitorianos: "there was [...] something plausible, superficial, unreal in all this abundance" (idem, p. 33). O problema seria a falta de representação das forças sociais que sustentavam a vida das personagens representadas: "it appeared that the basement was really in an appalling state. Thought the saloons were splendid and the dining room portentous, the drains were the most primitive description. The social state was a mass of corruption" (idem, p. 33).

Para os eduardianos, engajados nas questões de sua sociedade, esse apagamento tornara-se um problema, e os mesmos personagens (characters) de antes não mais davam conta de possibilitar uma apreensão significativa do mundo a seu redor. A necessidade de representar outro aspecto da vida resulta na necessidade de apreensão e de formulação de novos characters. No entanto, para Woolf, os eduardianos não perceberam que, ao mesmo tempo, outra mudança também estava em curso em relação à forma do romance:

there was another force which made much more subtly against the creation of character, and that was Mrs Garnett and her translations from Dostoevsky. After reading Crime and Punishment and The Idiot, how could any young novelist believe in 'characters' as the Victorians had painted them? For the undeniable vividness of so many of them is the result of their crudity. The character is rubbed into us indelibly because its features are so few and so prominent. (idem, p. 34)

A influência russa aponta para um novo caminho na elaboração do character, oposto ao dos escritores vitorianos, que compunham personagens vívidos, porém marcados por certa simplicidade. As características superficiais esparsas e proeminentes usadas pelos vitorianos criam personagens muito diferentes dos russos, que possuem poucos atributos externos, porém enorme profundidade subjetiva, segundo Woolf: "These are characters without any features at all. We go down into them as we descend into some enormous 
cavern" (idem, p. 34). Há, portanto, uma ampla necessidade, percebida tanto pelos eduardianos quanto pelos georgianos, gerada por motivos múltiplos, de se romper com as formas vitorianas, que se mostram progressivamente insuficientes. O principal problema do escritor eduardiano, para Woolf, foi não ter percebido a extensão e a natureza da renovação formal necessária.

Em "Character in fiction" (Woolf, 2008a), Woolf afirma, ainda, que uma nova mudança força os escritores de sua geração a encarar a insuficiência da forma do romance naquele momento:

on or about December 1910 human character changed. [...] The change was not sudden and definite. [...] All human relations have shifted-those between masters and servants, husbands and wives, parents and children. And when human relations change there is at the same time a change in religion, conduct, politics and literature. Let us agree to place one of these changes about the year 1910. (idem, p. 38)

Próximo a dezembro de 1910, ocorreu, em Londres, a Primeira Exposição Pós-Impressionista. Como indica Kenney Jr. (1977), o organizador da exposição, Roger Fry, e seus colaboradores, entre eles o marido de Woolf, descreveram da seguinte maneira a reação das pessoas que visitaram o evento: "people collapsing with laughter, erupting with rage, freezing in contempt, for the challenge posed by the Post-Impressionists was not merely aesthetic; it was social" (idem, p. 45). Tamanha reação indica que as mudanças formais propostas pelos impressionistas forçaram a percepção, pelo público, de um sentimento de modificação profunda da experiência humana no período. Segundo Woolf, essa mudança fundamental no caráter humano - aqui, character pode ser compreendido como caráter, no sentido de traço distintivo e essencial - impele o escritor a recusar as formas antigas de apreensão, que não dão mais conta da experiência humana de seu tempo.

Para seus contemporâneos, Woolf afirma que se faz premente um questionamento relacionado à inadequação daquilo queela chama de "convenção":

A convention in writing is not much different from a convention in manners. Both in life and in literature it is necessary to have some means of bridging the gulf between the hostess and her unknown guest on the one hand, the writer and his unknown reader on the other. (idem, p. 47)

A convenção, portanto, é a forma já estabelecida de um tempo; é o meiotermo entre o escritor e o leitor; é o que possibilita que um escritor escreva 
um texto que seus leitores reconheçam como um romance que lhes diz algo relevante a respeito do mundo. Segundo Woolf, as convenções existentes em seu tempo não mais cumpriam sua função essencial de estabelecer um meio comumente aceito de comunicação entre escritor e leitor; haviam, ao contrário, transformado o romance em uma forma que mecanicamente criava human characters com resultado um tanto artificial, como a autora pontua ironicamente: "The novel is a very remarkable machine for the creation of human character" (Woolf, 2008d, p. 32).

O caráter humano, em decorrência dessa ruptura sofrida no início do século $X X$, se tornou inapreensível pelas formas existentes, o que se reflete numa quebra das convenções preestabelecidas entre escritor e leitor. A forma do romance não é mais suficiente para representar o que se precisa representar, resultando na necessidade de estabelecimento de novas convenções, novas formas. Para Woolf, o que diferencia sua geração da dos eduardianos é a tomada de consciência da insuficiência das formas e da necessidade do estabelecimento de novas convenções. Por reconhecer que o romance está em crise, o escritor é impelido a experimentar radicalmente com as possibilidades do gênero.

Em primeiro lugar, se faz necessário um desmonte das formas então vigentes do romance, num processo que Woolf compara à demolição de um prédio: "And so the smashing and the crashing began. Thus it is that we hear all round us, $[\ldots]$ the sound of breaking and falling, crashing and destruction. It is the prevailing sound of the Georgian age" (Woolf, 2008a, p. 51). Essa destruição é inevitável, uma vez que as estruturas tradicionais do romance são vistas como um impedimento à apreensão da vida:

So much of the enormous labour of proving the solidity, the likeness to life, of the story is not merely labour thrown away but labour misplaced to the extent of obscuring and blotting out the light of the conception. The writer seems constrained, not by his own free will but by some powerful and unscrupulous tyrant who has him in thrall, to provide a plot, to provide come$d y$, tragedy, love interest, and an air of probability embalming the whole. [...] The tyrant is obeyed; the novel is done to a turn. But sometimes, more and more often as time goes by, we suspect a momentary doubt, a spasm of rebellion, as the pages fill themselves in the customary way. Is life like this? Must novels be like this? (Woolf, 2008c, p. 8)

A forma consolidada do romance - possuindo, para Woolf, enredo, comédia, tragédia, interesse amoroso, plausibilidade etc. - é comparada a um tirano que impede o romancista de escrever como precisa. Os entraves para a 
apreensão da vida pelo romance são justamente alguns dos aspectos formais que até então definiam o gênero: "the convention ceases to be a means of communication between writer and reader, and becomes instead an obstacle and an impediment" (Woolf, 2008a, p. 51).

Por essa razão, um descarte completo precisa ser realizado em primeiro lugar, mesmo que isso coloque o escritor numa situação precária frente à matéria: "the Georgian writer had to begin by throwing away the method that was in use at the moment. He was left alone there facing Mrs Brown without any method of conveying her to the reader" (idem, p. 49). A situação em que se encontra o escritor georgiano parece extremamente desfavorável - sozinho, não pode contar com nenhum método conhecido para realizar seu ofício. No entanto, essa instabilidade oferece uma oportunidade única de encontrar a liberdade: "the problem before the novelist at present, as we suppose it to have been in the past, is to contrive means of being free to set down what he chooses" (Woolf, 2008c, p. 11). Nesse caminho, não existem regras preestabelecidas, não existe certo e errado, há apenas a necessidade de se aproximar da matéria de maneira autêntica e não conformista:

Any method is right, every method is right, that expresses what we wish to express, if we are writers; that brings us closer to the novelist's intention if we are readers. (idem, p. 10)

Nothing —no 'method', no experiment, even of the wildest-is forbidden, but only falsity and pretence. 'The proper stuff of fiction' does not exist; everything is the proper stuff of fiction, every feeling, every thought; every quality of brain and spirit is drawn upon; no perception comes amiss. (idem, p. 12)

to have got at what I meant, I should have had to go back and back and back; to experiment with one thing and another; to try this sentence and that, referring each word to my vision, matching it as exactly as possible. (Woolf, 2008a, p. 49)

A experimentação, segundo Woolf, deve ser livre e sem limites, mas ao mesmo tempo precisa ser metódica, paulatina, exige comprometimento e possui um objetivo final claro, como vimos, que é a determinação de uma nova forma para o romance e de novas convenções, restabelecendo essa ligação entre a matéria, o escritor e o leitor: "somehow I had to find a common ground between us, a convention which would not seem to you too odd, unreal, and far-fetched to believe in" (idem, p. 49).

Não é uma tarefa fácil, e Woolf reconhece isso, admitindo inclusive 
que o resultado mais provável é o fracasso: "we must reconcile ourselves to a season of failures and fragments" (idem, p. 53). A vida, se for apreendida, virá, portanto, completamente fragmentada, algo para o que Woolf alerta o público inglês: "Tolerate the spasmodic, the obscure, the fragmentary, the failure" (idem, p. 54). Esse fracasso anunciado não impede que novas tentativas, novas experimentações sejam realizadas, e isso faz a geração de Woolf ser particularmente interessante:

Sadly he must allow that the lady still escapes him. Dismally he must admit bruises received in the pursuit. But it is because the Georgians, poets and novelists, biographers and dramatists, are so hotly engaged each in the pursuit of his own Mrs Brown that theirs is at once the least successful, and the most interesting, generation that English literature has known for a hundred years. (Woolf, 2008d, p. 35)

O fracasso é, para Woolf, um traço distintivo mas não absolutamente negativo de sua geração. Resultado direto e necessário do enorme esforço da empreitada de demolição e reconstrução das convenções do romance "where so much strength is spent on finding a way of telling the truth the truth itself is bound to reach us in rather an exhausted and chaotic condition" (Woolf, 2008a, p. 53) -, o fracasso sinaliza o comprometimento do escritor em se aproximar de um mundo que já não faz sentido quando visto pelos métodos tradicionais do gênero.

De fato, parece existir, para Woolf, uma dificuldade de apreensão da realidade inerente à escrita do romance, independentemente da geração do escritor. Faz parte da atividade do romancista conceber os próprios meios para realizar essa apreensão da realidade de maneira livre - retomando a citação: "the problem before the novelist at present, as we suppose it to have been in the past, is to contrive means of being free to set down what he chooses" (Woolf, 2008c, p. 11). A necessidade de rompimento com formas já estabelecidas, mas que não mais dão conta do que se precisa representar, seria uma constante do gênero. De geração em geração, o character antes aparentemente apreendido escapa, porque o que se entende por character muda e a elaboração de novos meios de apreensão se faz necessária. As crises, desse modo, tanto do romance quanto do indivíduo, constituem a própria história do gênero. O que parece haver, na geração de Woolf, é uma marcada intensificação desse processo: "we look back with envy to those happier warriors, whose battle is won and whose achievements wear so serene an air of accomplishment that we can scarcely refrain from whispering that the fight was not so fierce for them as for us" (idem, p. 8). 
Essa ideia de intensificação de um processo histórico é retomada em mais um de seus ensaios, "How it strikes a contemporary", em que Woolf sinaliza como sua geração é mais engajada que as anteriores em romper com as convenções do passado: "no age can have been more rich than ours in writers determined to give expression to the differences which separate them from the past" (Woolf, 2008b, p. 27).

Nesse ensaio, Woolf argumenta ainda que esse rompimento se faz particularmente necessário em sua geração porque a experiência em si deixou de ser comunicável. No passado, o romancista conseguia apreender totalmente a experiência e representá-la de maneira completa ao leitor: "The little grain of experience once selected, believed in, and set outside herself, could be put precisely in its place, and she was then free to make it, by a process which never yields its secrets to the analyst, into that complete statement which is literature" (idem, p. 29). A descrença nessa possibilidade de apreensão e transmissão é o grande entrave do escritor contemporâneo segundo Woolf:"our contemporaries afflict us because they have ceased to believe" (idem, p. 29).

Discorrendo sobre a impossibilidade de transmissão da experiência, Benjamin $(1985,1989)$ também vêque há, no início do século XX, a intensificação de um processo de declínio da narrativa tradicional, aquela que possuía em si a dimensão utilitária da transmissão de um conselho, da transmissão da experiência de um indivíduo a outro. Essa narrativa tradicional estaria sendo progressivamente substituída por outras formas, como a informação, preocupada com a transmissão simples e precisa de acontecimentos. Assim, a capacidade de se internalizar e narrar a experiência estaria se perdendo. Para o romance, essa crescente impossibilidade de comunicação da experiência leva a um impasse, postulado da seguinte maneira por Adorno: "não se pode mais narrar, embora a forma do romance exija a narração" (2003, p. 55).

Diante desse impasse, Woolf acredita que cabe à sua geração o papel importante mas inglório de "pôr a casa em ordem" para as gerações futuras: "It seems as if an age of genius must be succeeded by an age of endeavour; riot and extravagance by cleanliness and hard work. All honour, of course, to those who have sacrificed their immortality to set the house in order" $2008 \mathrm{~b}$, p. 26). Ao escritor de sua geração Woolf atribui esse trabalho de criação não de obras-primas, mas de um alicerce sólido sobre o qual obras melhores possam se erguer futuramente:

it would be wise for the writers of the present to renounce the hope of creating masterpieces. Their poems, plays, biographies, novels are not books but notebooks. [...] Other students will find them very useful. It is from notebooks of the present that the masterpieces of the future are made. (idem, p. 30) 
Novamente, a autora reforça a ideia de que as obras dos escritores que participarem da elaboração desse alicerce provavelmente não se eternizarão como clássicos: "as if they are engaged upon some vast building, which being built by common effort, the separate workmen may well remain anonymous" (idem, p. 30).

A potencial falta de importância histórica futura e a improbabilidade da elaboração de grandes obras não resultam em uma perspectiva necessariamente pessimista, segundo Woolf:

It is a barren and exhausted age, we repeat; we must look back with envy to the past. Meanwhile it is one of the first fine days of spring. Life is not altogether lacking in colour. [...] Our optimism, then, is largely instinctive. It springs from the fine day and the wine and the talk. (idem, p. 26-27)

A própria necessidade de renovação é, em si, animadora: "Every day we find ourselves doing, saying or thinking things that would have been impossible to our fathers" (idem, p. 27). As novidades que se apresentam à vida tornam o presente único, e Woolf pontua que apenas uma nova forma de literatura pode surtir o mesmo efeito:

And modern literature, with all its imperfections, has the same hold on us and the same fascination. [...] It has the same endearing quality of being that which we are, that which we have made, that in which we live, instead of being something, however august, alien to ourselves and beheld from the outside. (idem, p. 27)

No entanto, a incapacidade da forma de apreender totalmente essa matéria nova força os ânimos a se alternarem entre esse otimismo do encontro com as novas possibilidades e o pessimismo da frustração a cada fracasso em superar a crise posta:

Book after book leaves us with the same sense of promise unachieved, of intellectual poverty, of brilliance which has been snatched from life but not transmuted into literature. [...] We are back at the beginning, vacillating from extreme to extreme, at one moment enthusiastic, at the next pessimistic, unable to come to any conclusion about our contemporaries. (idem, p. 28)

De modo geral, o tom otimista dos ensaios parece se justificar não apenas pela constatação das possibilidades do tempo presente, mas pela perspectiva 
futura que Woolf antevê. Todo o movimento de demolição e desmonte identificado como necessário pela autora aponta para a eventual superação da crise e o estabelecimento de novas convenções. É essa crença nas possibilidades que sua geração cria para a construção futura de grandes obras que parece permitir, em grande medida, o otimismo com que Woolf encara a instabilidade de sua época; afinal, como vimos anteriormente, "it is from notebooks of the present that the masterpieces of the future are made" (idem, p. 30).

Como pudemos perceber, em seus ensaios, Woolf procura, por um lado, compreender o que constitui o romance enquanto gênero, para, por outro lado, poder discutir os problemas específicos de sua geração. De maneira geral, Woolf concebe o romance como contendo, necessariamente, um conflito interno em relação à possibilidade de representar o mundo. $\mathrm{O}$ que define o gênero romance, para a autora, é uma preocupação com a apreensão e a representação de um character, que é tanto uma personagem na obra quanto um traço fundamental da experiência humana materializado num indivíduo real e percebido por um escritor. O mundo só pode ser figurado no romance quando posto em relação a esse character, que por sua vez só ganha contornos a partir do contraste com o mundo. Nesse processo, o leitor acaba separado da matéria por duas camadas de filtragem: na primeira, character e mundo só são percebidos, ainda que de modo parcial, quando espelhados um no outro; na segunda, um escritor, por sua vez, consegue entrever apenas certos aspectos de determinado character. Woolf percebe que, desde o surgimento do romance, certas convenções foram sendo estabelecidas para intermediar esse processo e aproximar o leitor, o escritor e a matéria.

Em relação à própria geração de escritores, Woolf constata a incapacidade dessas convenções de dar conta dessa intermediação. O problema seria resultado de uma mudança significativa na matéria do romance, na experiência humana materializada na figura dupla do character. Com bastante otimismo, mesmo diante da constante frustração, Woolf atribui à sua geração a missão de, primeiramente, demolir as convenções estabelecidas para, a seguir, construir novas maneiras de aproximar representação e matéria e de estabelecer o contrato entre escritor e leitor.

No conto"An unwritten novel", Woolf aponta para alguns desdobramentos dessas mesmas questões e as trabalha não simplesmente enquanto conteúdo, mas principalmente por meio da forma literária. Como vimos, a ligação mais imediata entre esse conto e os ensaios é perceptível em seu enredo, que se utiliza dos mesmos elementos que compõem o episódio central de "Character in fiction": um encontro fortuito em um vagão de um trem com uma mulher mais velha que impressiona fortemente a pessoa que a observa; a atribuição de um nome a essa mulher; o sentimento de sofrimento e de dor percebido na figura dela; e a necessidade de se tentar apreender e narrar sua história a 
partir da impressão e das sensações causadas pelo encontro. No ensaio, Woolf usa essa história para apresentar um acontecimento supostamente verídico que exemplifica o nascimento de um romance na mente do escritor. Podemos perceber, assim, que, mesmo sem mencionar o processo de escrita em si, por seu título e pela proximidade com esse ensaio, o conto está trabalhando com os elementos da elaboração e composição de um romance.

No ensaio, o encontro com a mulher divide-se em três momentos. Primeiramente, a escritora observa apenas a mulher, a quem prontamente nomeia Mrs. Brown, e atenta para a tristeza de seu semblante e para a pobreza que a arrumação aparentemente forçada de sua vestimenta deixa transparecer. São observações e caracterizações que partem de elementos externos, das roupas, do semblante, da estatura da mulher, mas que logo forçam à mente da escritora um sentimento da existência de uma história por trás daquela figura:

I felt that she had nobody to support her; that she had to make her mind for herself; that having been deserted, or left a widow, years ago, she had led an anxious, harried life, bringing up an only son, perhaps, who, as likely as not, was by this time beginning to go to the bad. (Woolf, 2008a, p. 39)

Como podemos perceber, a partir de breves impressões e observações a respeito da aparência da mulher, Woolf imediatamente começa a tecer-lhe uma história. No segundo momento, a atenção recai também sobre o homem, mais jovem, que acompanha essa mulher, e sobre o diálogo travado pelos dois. O homem ganha um nome, Mr. Smith, mas recebe menos atenção da escritora, interessada apenas em sua relação com Mrs. Brown. Mais do que os tópicos da conversa entre os dois, Woolf observa as inflexões de voz, os olhares e os sentidos escondidos por trás das falas aparentemente banais. Em dado momento, a mulher do vagão começa a chorar no meio de um monólogo do rapaz a respeito de um assunto absolutamente corriqueiro e distante dela. Pela reação dele, o choro da mulher é algo comum, mas mesmo assim ele acaba se incomodando, troca mais algumas palavras e vai embora do vagão. Nesse terceiro momento, quando Woolf está sozinha com a mulher, a impressão causada anteriormente se intensifica e toma a escritora por completo:

Mrs Brown and I were left alone together. She sat in her corner opposite, very clean, very small, rather queer, and suffering intensely. The impression she made was overwhelming. It came pouring out like a draught, like a smell of burning. What was it composed of - that overwhelming and peculiar impression? Myriads of irrelevant and incongruous ideas crowd into one's head 
on such occasions; one sees the person, one sees Mrs Brown, in the centre of all sorts of different scenes. (idem, p. 41)

Woolf então descreve uma série de cenas com a mulher no centro. Essas cenas importam menos pelos detalhes que revelam sobre a vida da mulher do que por permitirem um mergulho intenso na atmosfera da personagem: "but details could wait. The important thing was to realise her character, to steep oneself in her atmosphere" (idem, p. 42). O uso contínuo de termos como "I felt", “I imagined", "impression" e também as imagens usadas para descrever o sentimento causado pela impressão (por exemplo, "It came pouring out like a draught, like a smell of burning", acima) indicam que esse é um processo não completamente racional, mas baseado em sensações e intuições. Ao mesmo tempo, diversas expressões que se repetem, como "as if", "maybe", "perhaps" e "it might have been", reforçam a incerteza e a indefinição dessa apreensão.

O episódio se encerra sem que Woolf saiba como a história daquela mulher termina, sem que atinja uma compreensão maior da personagem. Ao final, desafiando a racionalidade do ordenamento de uma história em direção a um desfecho, a um propósito, o encontro parece não possuir um sentido maior: "The story ends without any point to it" (idem, p. 42).

O conto modifica os detalhes dessa narrativa e a estende significativamente. A cena do trem é vista por um narrador em primeira pessoa, que, numa posição análoga à de Woolf na história relatada no ensaio, observa outros passageiros em um vagão de trem. A primeira diferença que podemos notar é a presença de mais gente no vagão, mas logo todos saem, um a um, e o narrador se vê sozinho com a mulher. Não existe a personagem do homem um pouco mais jovem acompanhando essa mulher, que agora está viajando sozinha; no conto, é o narrador quem estabelece uma conversa corriqueira e não muito confortável com ela. É a partir desse contato direto com seu objeto de fascínio que o narrador procura apreender a história que começa a desenhar em seguida.

A cena do trem, que ocupa principalmente as duas páginas e meia do início do conto e a meia página final, parece, em um primeiro momento, servir de moldura para a história narrada sobre a vida da mulher, que ocupa a maior parte do conto, se estendendo por sete páginas. Dentro da história que o narrador vislumbra para a mulher do trem, outras diferenças em relação ao episódio relatado no ensaio podem ser percebidas. O nome dado à personagem é outro - não Mrs. Brown, mas Minnie Marsh -, e a história criada é bastante diferente. Mrs. Brown estava envolvida em problemas financeiros por causa de seu filho; Minnie Marsh nunca se casou, tampouco tem filhos, e tem uma relação complicada com a esposa de seu irmão. 
Se essas mudanças nos detalhes não parecem realmente significativas para nossa discussão, uma vez que não necessariamente afetariam a forma do romance, servem, pelo menos, para evidenciar o tipo de relação que podemos esperar entre o conto e os ensaios: não apenas a repetição estendida das mesmas ideias, mas outra perspectiva sobre o mesmo assunto. Para podermos, de fato, compreender o que o conto nos diz sobre a forma romance, precisamos ir além dos detalhes de enredo e examinar com mais atenção sua própria construção, sua própria forma.

Há um sentimento de frustração presente no título de "An unwritten novel", que indica a tentativa fracassada de escrita de um romance. Esse sentimento é reforçado pela estrutura em dois níveis na qual o conto é construído: há uma história-moldura, a cena do trem narrada em primeira pessoa, e uma história interna, que poderia perfeitamente se passar por uma narração em terceira pessoa, que é a história que o narrador cria sobre Minnie Marsh.

No decorrer do conto, a história interna parece predominar, ocupando maior espaço e possuindo um enredo mais desenvolvido. Na históriamoldura, praticamente não há ações externas significativas, com exceção de alguns espasmos da mulher que se senta à frente do narrador e de um breve diálogo sobre coisas cotidianas. Já na interna, temos personagens que possuem nomes próprios, são razoavelmente definidos e entram em choque uns com os outros. Há conflito, há a potencialidade de um relacionamento amoroso, e há um trauma fundamental que assombra a personagem central. Contudo, esses elementos não compõem um enredo tradicional regido pela causalidade ou pela cronologia dos acontecimentos. Conhecemos a história de Minnie Marsh por meio de flashes que assaltam sua mente sem ordem alguma e nos mostram uma mulher solteira e sem filhos que tem uma relação turbulenta com a cunhada. As memórias e os pensamentos vão se sucedendo num movimento que se intensifica até apontarem para um momento de resolução interna, um clímax, que não chega.

Logo antes desse clímax potencial, a história interna é interrompida pela moldura. $\mathrm{O}$ trem chega à estação final, e o narrador observa a mulher ser recebida por um jovem rapaz que a chama de mãe, invalidando por completo a veracidade da história que havia sido criada. O desenvolvimento da ação da narrativa sobre Minnie Marsh é interrompido pelo confronto com a realidade, e o conto, afinal, termina sem um ponto culminante que sirva para estruturar uma direção e um senso de causalidade para a sucessão de acontecimentos que o precedem. É um momento duplo de surpresa negativa: tanto a expectativa do leitor é frustrada por um enredo anticlimático quanto a do narrador, que percebe não ter conseguido apropriar-se da história da pessoa à sua frente. Se a história de Minnie era a mais visível, sua interrupção e, acima 
disso, sua negação poderiam caracterizar a estrutura do conto inteiro como algo centrado em um vazio, em uma ausência de significados possíveis de serem apreendidos, resultando em um texto bastante pessimista. Esse vazio potencial também se faz sentir ao final do episódio de "Character in fiction", se lembrarmos que, no ensaio, Woolf declara: "The story ends without any point to it" (idem, p. 42).

O final do conto, ao contrário, é marcadamente otimista: após a frustração de descobrir que sua história era falsa, ao invés de recuar, o narrador avança sobre o mundo, buscando, com entusiasmo, novas histórias, a partir de novos objetos. Esse movimento expansivo após a frustração oferece uma segunda surpresa para o leitor, que se vê agora na posição de reavaliar o conto por outras perspectivas se quiser compreender como esse otimismo final se constitui.

Segundo Piglia, "um conto sempre conta duas histórias" (2004, p. 89), o que significa que, trabalhando com a forma conto, um escritor deve construir um texto em que os elementos formais possuam pelo menos duas faces, apontando para duas construções narrativas simultâneas: "cada uma das histórias é contada de modo distinto. Trabalhar com duas histórias quer dizer trabalhar com dois sistemas diferentes de causalidade. Os mesmos acontecimentos entram simultaneamente em duas lógicas narrativas antagônicas" (idem, p. 90).

Como já vimos, "An unwritten novel" de fato possui duas histórias, facilmente identificáveis. O choque causado pela interrupção da história interna reposiciona a história-moldura no centro da atenção do leitor e nos força a repensar a relação entre as duas. Somos impelidos, então, a retornar ao início do conto e relê-lo, observando como, enquanto estávamos distraídos pela empolgante narração da história de Minnie Marsh, outra história se construía em segundo plano, a partir dos elementos visíveis da história de superfície.

Quando o conto começa, o narrador descreve cinco pessoas presentes em um vagão de trem, procurando em suas feições algo que chama de "vida", que ele define da seguinte maneira: "Life's what you see in people's eyes" (Woolf, 1989, p. 112). O narrador ecoa, assim, a relação que apontamos previamente entre vida e character. Os quatro primeiros passageiros se esforçam para esconder a vida, e logo o narrador se desinteressa deles. A quinta passageira, no entanto, não faz esforço algum, e uma enorme tristeza transforma seu semblante em algo maior: "Such an expression of unhappiness was enough by itself to make one's eyes slide above the paper's edge to the poor woman's face-insignificant without that look, almost a symbol of human destiny with it" (p. 112). É essa tristeza o elemento que primeiro fascina o narrador, que só então se revela como um sexto passageiro no vagão. Até 
aqui, poderíamos estar diante de um narrador onisciente em terceira pessoa; apenas após estabelecer sua relação com a mulher esse narrador consegue assumir sua posição enquanto sujeito presente na cena.

O segundo traço da mulher que fascina o narrador são uns pequenos espasmos, provavelmente involuntários, que ela sofre. $\mathrm{O}$ narrador primeiro tenta resistir ao fascínio que sente, escondendo o rosto atrás do jornal que segura nas mãos, mas o olhar triste da mulher e um novo espasmo negam essa possibilidade. O narrador começa, então, a procurar maneiras de compreender a mulher.

É uma sucessão de ações exteriores que fazem o narrador sentir que pode apreender a interioridade da mulher. Primeiro ela esfrega um pedaço do vidro da janela, como se tentasse eliminar uma mancha, uma contaminação que não é removida: "She rubbed as if she would rub something out for ever-some stain, some indelible contamination. Indeed, the spot remained for all her rubbing" (p. 113). Depois, a mulher sofre um pequeno espasmo. $O$ narrador se sente impelido a imitá-la esfregando também a janela a seu lado e sofrendo, em seguida, um espasmo. A mulher percebe o espelhamento que está acontecendo e lança um breve sorriso irônico e triste: "She saw me. A smile of infinite irony, infinite sorrow, flitted and faded from her face. But she had communicated, shared her secret, passed her poison; she would speak no more" (p. 114). O narrador, então, sente que houve uma transmissão, uma comunicação em um nível além do verbal; há um forte reconhecimento mútuo que permite que, mesmo sem conseguir olhar para ela, ele possa narrar sua história: "Leaning back in my corner, shielding my eyes from her eyes, seeing only the slopes and hollows, greys and purples, of the winter's landscape, I read her message, deciphered her secret, reading it beneath her gaze" (p. 114). Não é, no entanto, um processo fácil para o narrador, uma vez que as imagens usadas para descrever a cena remetem à contaminação dele pela outra.

O parágrafo seguinte se inicia já dentro dessa outra história com o seguinte trecho: "Hilda's the sister-in-law. Hilda? Hilda? Hilda Marsh—Hilda the blooming, the full bosomed, the matronly" (p. 114). Nesse momento, a visão do leitor é forçada a olhar para as duas histórias simultaneamente. Ao mesmo tempo que somos apresentados à cunhada, que é a primeira personagem a receber nome próprio no conto, somos lembrados do processo de construção da história, ao vermos o narrador escolhendo o nome para a personagem.

Em diversas outras passagens ao longo do conto, o narrador nos mostra esse processo de construção da história de Minnie Marsh. Ele, por exemplo, edita e seleciona as cenas que são importantes para sua narração: "this we'll skip; ornaments, curtains, trefoil china plate, yellow oblongs of cheese, white squares of biscuit-skip" (p. 114). Em outro momento, interrompe a narração e, entre parênteses, olha, no trem, para a mulher a sua frente em busca de 
sinais que confirmem a história: "(Let me peep across at her opposite; she's asleep or pretending it; so what would she think about sitting at the window at three o'clock in the afternoon? Health, money, bills, her God?)" (p. 115). Além disso, ele comenta o desenvolvimento da própria narração, como quando perde o controle sobre a personagem e ela Ihe escapa: "That's what always happens! I was heading her over the waterfall, straight for madness, when, like a flock of dream sheep, she turns t'other way and runs between my fingers. [...] Have I read you right?" (p. 116). Há ainda um momento em particular em que o narrador insere uma marca de pontuação na história: "She opened the door, and, putting her umbrella in the stand-that goes without saying: so, too, the whiff of beef from the basement; dot, dot, dot" (p. 117). Assim, temos evidenciada sua capacidade de moldar o texto, de criar a história: é ele quem ordena a pontuação, o ritmo, as palavras, os lugares, as ações. Percebemos, afinal, que a narrativa interna não é apenas a vida de Minnie Marsh, mas é também o próprio processo de criação dessa história pelo narrador.

Nesse conto, mais do que o registro de uma pessoa real, o processo de elaboração de uma personagem (character) é interno ao narrador. O próprio charactera ser representado é, como vemos no conto, não simplesmente a mulher no trem, nem seu retrato preciso, mas Minnie Marsh, uma construção textual feita sob nosso olhar pelo narrador a partir de seu contato com a matéria real.

O narrador espelha, primeiro em si e depois na personagem que cria, os traços da mulher do trem a que tem acesso; elementos a princípio externos, como os espasmos, ou inferidos a partir da breve conversa que travam. Ao mesmo tempo, o narrador projeta sobre Minnie Marsh os elementos do mundo que lhe interessam narrar e que pode articular em relação à imagem que criou da mulher à sua frente. É uma relação em mão dupla. O narrador espelha da personagem aquilo que the causa uma forte impressão, e vê espelhado na personagem aquilo que do mundo o interessa.

Dessa maneira, a figura que parece estar no centro do conto, mais do que Minnie Marsh, é o próprio narrador, e a linha-guia que estrutura o texto não é somente o enredo fragmentado da vida da personagem, mas a trajetória do narrador em sua tentativa de apreender e elaborar um character que lhe seja autêntico.

Ao longo do conto, o narrador progressivamente assume novas posições. Como já vimos, no início é uma consciência tímida, que não consegue se colocar em cena antes de definir uma personagem em relação à qual possa se estabelecer. Apenas quando reconhece seu interesse pela mulher de olhar triste é que o narrador consegue se revelar como personagem e assumir sua posição enquanto sujeito presente na cena.

Adiante, quando começa a narrar a história de Minnie Marsh, o narrador adquire uma forma ainda mais complexa. Tendo em vista o final do conto, 
sabemos que a mulher do trem e Minnie não são a mesma pessoa, o que nos permite perceber como o narrador se posiciona diferentemente em relação a cada uma dessas personagens. No vagão do trem, ele olha para a mulher de frente e é ele mesmo uma personagem inserida no limitado espaço da cena, narrada de maneira temporalmente linear. Ao elaborar a história interna, o narrador assume a posição de uma entidade não corpórea, que pode mergulhar na subjetividade de sua personagem e olhar para ela de dentro, além de ter a possibilidade de realizar saltos temporais e espaciais, seguindo o fluxo de memórias que assaltam a mente de Minnie. Além disso, como ele, afinal, não reproduz a vida de outra pessoa, mas cria uma personagem por conta própria (ainda que inspirado no encontro do trem), possui onisciência e onipotência plenas quando narra a história interna: tudo o que é apresentado é criação sua, e nós testemunhamos o processo e o momento exato dessa criação.

Quando percebe que a história que contava e a realidade não correspondem uma à outra e que não havia conseguido alcançar seu desejo inicial de apreender e reproduzir a vida que enxergara no outro, o narrador se mostra irritado e confuso:

Well, but I'm confounded... Surely, Minnie, you know better! A strange young man... Stop! I'll tell him-Minnie!-Miss Marsh!-ldon't know though. There's something queer in her cloak as it blows. Oh, but it's untrue, it's indecent... Look how he bends as they reach the gateway. She finds her ticket. What's the joke? Off they go, down the road, side by side... Well, my world's done for! What do I stand on? What do I know? That's not Minnie. There never was Moggridge. Who am I? Life's bare as bone. (p. 121)

O narrador reluta em aceitar que Minnie Marsh não existiu no mundo real, que a mulher do trem the escapou. Da percepção de que Minnie não existiu, o narrador declara que seu mundo acabou ("my world is done for!"), sente ter perdido a sustentação de seu conhecimento de mundo ("What do I stand on? What do I know?") e questiona a própria identidade ("Who am I?"). Como vimos, somente após avistar a mulher no trem é que o narrador havia se posicionado em cena, sempre em relação a esse objeto que o fascinara. Perdendo a sensação de apreensão desse objeto, fica sem aquilo que o sustentava em cena, que the permitia se posicionar no mundo, e chega a contestar a própria identidade, que havia se constituído de maneira relacional à mulher. O resultado, como pudemos ver, é um desespero e uma confusão que transparecem até na construção das frases curtas e fragmentadas do trecho citado. Porém, esse desespero dura pouco, e já no parágrafo seguinte o narrador se reafirma em nova posição: 
And yet the last look of them-he stepping from the kerb and she following him round the edge of the big building brims me with wonder-floods me anew. Mysterious figures! Mother and son. Who are you? Why do you walk down the street? Where to-night will you sleep, and then, to-morrow? Oh, how it whirls and surges-floats me afresh! I start after them. People drive this way and that. The white light splutters and pours. Plate-glass windows. Carnations; chrysanthemums. Ivy in dark gardens. Milk carts at the door. Wherever I go, mysterious figures, I see you, turning the corner, mothers and sons; you, you, you. I hasten, I follow. This, I fancy, must be the sea. Grey is the landscape; dim as ashes; the water murmurs and moves. If I fall on my knees, if I go through the ritual, the ancient antics, it's you, unknown figures, you I adore; if I open my arms, it's you I embrace, you I draw to me-adorable world! (p. 121)

Ao invés de recuar após o fracasso, o narrador avança em direção ao mundo. Primeiramente, a mulher do trem e seu filho se tornam um novo mistério e encantam o narrador, que se sente novamente impelido a descobrir as histórias dessas personagens. As sensações tornam a arrebatar o narrador, e as imagens utilizadas remetem à água e à submersão: "floods me anew", "floats me afresh". A seguir, novos objetos chamam a atenção do narrador, que percebe a existência de outras pessoas nas ruas e, a partir delas, de outros detalhes do espaço. $O$ movimento é expansivo, e logo o narrador descreve o mar e o cenário como grandes corpos de cor cinza. A matéria é vista de cima, numa posição impossível de ser assumida por uma pessoa comum, como o narrador havia se apresentado na cena inicial do conto. Há uma espécie de comunhão ritualística com a matéria nas frases finais do conto, que assumem um tom eufórico, extático, e o interesse pelas figuras desconhecidas se transforma em adoração na tentativa de abarcar o mundo inteiro.

Tendo em vista a centralidade da apreensão e elaboração de um character para a forma do romance, proposta por Woolf nos ensaios, podemos compreender o breve, porém impactante, momento de desespero sentido pelo narrador ao perceber que a representação elaborada não correspondia à realidade concreta; ou, em outras palavras, que o character que procurou apreender the escapou. A euforia que se segue e o movimento ascendente em termos de posicionamento em relação à matéria são mais difíceis de serem compreendidos nesses mesmos termos. $O$ esperado seria um recuo após o choque, mas o que acontece é o oposto. Ao longo do conto, a tensão existente entre o narrador e a matéria narrada é progressivamente trazida à vista e é levada ao limite quando o trem chega à estação. Por um instante, 
a intensificação dessa tensão ameaça romper a relação sujeito-mundo, separando de vez os dois polos, mas, ao contrário, acaba servindo de impulso para que o narrador redobre seu interesse e avance sobre a matéria.

O tamanho do choque sentido pelo narrador se explica por dois fatores. Em primeiro lugar, como sugerimos anteriormente, para Woolf é fundamental que o romance represente um character, esse é o propósito do gênero. Além disso, o próprio narrador de "An unwritten novel" depende de sua relação com essa personagem que o fascina para se estabelecer em cena; afinal, no início do conto, ele só consegue se definir como personagem dentro do vagão a partir do encontro com a mulher. Sem essa apreensão, poderíamos supor que o romance não se sustentaria enquanto forma e que o narrador perderia as bases da própria identidade. O movimento que se segue, no entanto, é não um retraimento, mas uma expansão eufórica sobre a matéria.

A maneira como Woolf enxerga a crise do romance em seu próprio tempo nos oferece uma primeira hipótese de interpretação para esse movimento final do narrador. Essa alternância entre a angústia que o leva a questionar a própria existência e a euforia que o faz avançar em direção a novos objetos espelha ideias da autora a respeito da condição de seus contemporâneos. $O$ narrador, ao final, percebe que sua posição em relação à matéria é precária, mas, ao mesmo tempo, seu próprio percurso até ali indica meios de se reposicionar, de se reestruturar. Afinal, desde o início do conto, o narrador não mantém apenas uma posição fixa e estável em relação à matéria. Ele se altera de narrador aparentemente em terceira pessoa para narrador-personagem posto em relação à mulher do vagão e termina como uma entidade onisciente que vê o mundo de cima. Mais do que uma pessoa no trem, a quem o impulso expansivo do final do conto seria impossível, o narrador é uma ferramenta literária experimentando a própria forma em sua tentativa de representar o mundo, e suas possibilidades formais, como seu movimento ao longo do conto indica, tendem ao ilimitado.

A trajetória do narrador, como podemos perceber, é caracterizada por uma série de mudanças em relação à própria posição e à própria forma, algo que indica a complicada relação entre ele e a matéria estabelecida, portanto, desde o princípio do conto. A chegada do trem à estação força, assim, uma tomada de consciência dessa complexidade - passo fundamental para que ele possa reconstruir sua relação com seus objetos e se reaproximar deles.

Na figura desse narrador, seguindo essa interpretação, Woolf representa a situação do romance no início do século XX: precisando questionar todos os aspectos de sua própria forma e sua relação com a matéria; assumindo a experimentação errante como meio de encontrar novos meios de apreensão do mundo; procurando indivíduos que o interessem para poder, a partir da representação deles em sua totalidade, representar o mundo; e por vezes 
falhando, mas "limpando a casa" e abrindo caminhos para gerações futuras. O otimismo do parágrafo final do conto poderia indicar, portanto, o início dessa parte posterior do movimento dos escritores contemporâneos a Woolf, quando a consciência da crise do romance leva à demolição das formas e aponta para a superação futura da própria crise.

O que devemos questionar, no entanto, é a relação entre romance e crise que esse movimento pressupõe. Visto desse modo, o romance tenderia à estabilidade, à superação de suas crises, das quais essa, no início do século XX, seria apenas a mais recente e a mais pronunciada. No entanto, diversos críticos apontam para a maneira como o romance, desde seu surgimento, trabalha com uma série de contradições e crises. Para Lukács (2009), por exemplo, o que diferencia o romance da epopeia é o estabelecimento da sociedade de classes, cujas contradições apenas a forma do romance consegue apreender. As contradições de seu tempo estão, portanto, no centro da forma, que deve necessariamente representar essa tensão. Ademais, para esse crítico, na sociedade burguesa "as forças sociais se manifestam [...] de modo abstrato, impessoal e inapreensível pela narração poética" de modo que a natureza dessa sociedade não favorece "uma tomada de consciência imediata e clara das contradições sociais fundamentais" (idem, p. 207-208). Em um mundo em que o indivíduo perde sua agência para forças externas, torna-se impossível para ele perceber e compreender de maneira total como suas ações afetam os outros, como ele se encaixa nos conflitos sociais de que participa. Como, para Lukács, o romance precisa se constituir a partir de um indivíduo típico cuja ação permita o desvelamento paulatino da totalidade dos conflitos que compõem a sociedade, o fato de, na sociedade burguesa, a ação não necessariamente estar sob o controle do indivíduo significa que, para o romance, a matéria a ser apreendida e a forma literária estão em conflito:"para os grandes romancistas, o problema da forma consiste em superar esta hostilidade do material com que trabalha" (idem, p. 208).

Por um caminho diferente, McKeon (1988) explora como o romance surge durante a crise de representação e de valores da qual nasce também o mundo moderno. Esse autor discute como a ascensão do romance é, na realidade, um processo dialético em que formas de compreensão do mundo e valores antigos e modernos convivem antagonicamente, em crise. O romance se configura não simplesmente como um conjunto moderno de formas e temas que suplanta o anterior, mas justamente como palco para o conflito: “The genre of the novel can be understood comprehensively as an early modern cultural instrument designed to confront, on the level of narrative form and content, both intellectual and social crisis simultaneously" (idem, p. 178). Desse modo, o romance é uma forma na qual, como fruto das crises de seu tempo, o escritor explora meios novos de expressão. Um certo ímpeto exploratório, 
portanto, caracteriza o gênero. Tanto para Lukács quanto para McKeon, ainda que de maneiras bastante distintas, o romance surge justamente como palco privilegiado para a representação dialética de elementos antagônicos em crise e para o confronto com uma matéria que se recusa a ser apreendida de maneira reducionista.

O maior problema com nossa primeira hipótese de interpretação do final do conto parece estar, portanto, em destacar uma antecipação da superação da crise como explicação para o avanço do narrador sobre a matéria depois de sua frustração. Parece-nos, ao contrário, que a crise é, também, um elemento constitutivo do próprio gênero romance.

Se os ensaios de Woolf apontam para a necessidade de superação da crise para que a vida seja novamente apreensível pelo romance, o conto aponta um caminho mais complexo. A tomada de consciência da crise pelo narrador força também o leitor a perceber como essa tensão estava presente desde o início. Quando voltamos e analisamos novamente o conto colocando em primeiro plano não a história incompleta de Minnie Marsh, mas o desenvolvimento do próprio narrador, percebemos que, se por um lado ele fracassa em apreender a matéria imediata, o character da mulher no trem, por outro ele é bemsucedido em apreender, em sua própria forma, uma matéria mais profunda.

O movimento de transformação do narrador no decorrer do conto constitui-se em um percurso narrativo próprio: a ação central do conto, que o define e o estrutura, é a tentativa de apreensão da matéria e de elaboração de uma narração. Dessa maneira, em sua trajetória ao longo do conto, o narrador interioriza uma série de questionamentos urgentes à época e materializa em sua própria forma, por um lado, a crise do romance e a crise do indivíduo que estão em curso no início do século XX e, por outro, a empolgação dos escritores do período com o amplo horizonte de novas possibilidades decorrente das rupturas causadas por essas diversas crises. Assim, esse narrador representa historicamente o próprio mundo, o próprio tempo, e desse modo se autoriza a avançar confiante sobre a matéria, ainda que a confiança provenha não somente do sucesso, mas também do fracasso. O desejo, apresentado por Woolf nos ensaios, de superar a crise do romance parece dar lugar, no conto, à admissão de que a noção de crise é constitutiva do romance e de que o caminho a seguir é dar forma às especificidades das contradições de seu tempo, para assim se reaproximar da matéria.

Observado ao lado dos ensaios, o conto "An unwritten novel" nos oferece a seguinte pergunta: qual seria, afinal, o character que esse romance não escrito estaria tentando apreender? A resposta imediata, obviamente, é a figura da mulher do trem espelhada em Minnie Marsh, a mulher cuja história o narrador tenta apreender e fracassa: não conseguindo, como indica o título, escrever um romance. No entanto, não é na personagem dupla da mulher do 
trem e de Minnie Marsh que Woolf figura a crise do romance, mas no próprio narrador do conto. $\mathrm{O}$ título do conto nos aponta para o malsucedido processo de escrita de um romance, pelo narrador, em sua tentativa de constituir um character que ao mesmo tempo seja forma literária, Minnie Marsh, e apreenda satisfatoriamente um aspecto real da experiência humana, a mulher do trem. Se o narrador fracassa em apreender a matéria, cristalizada no character da mulher do trem, o conto, por outro lado, é bastante bem-sucedido no mesmo propósito, figurando um aspecto da experiência do início do século XX não simplesmente nas personagens que compõem o enredo, mas no próprio narrador, que é, desse modo, ele mesmo um character no sentido mais amplo da palavra que apresentamos anteriormente: um aspecto fundamental da experiência humana apreendido e materializado numa forma literária. A tentativa, a princípio frustrada, de apreender e representar a mulher no trem foi, ao mesmo tempo, o processo bem-sucedido de apreensão e representação, na figura do narrador, da crise pela qual o romance passava. "An unwritten novel", desse modo, é um conto que usa a própria forma especificamente a elaboração de seu narrador - para levantar uma série de questões que implicam diretamente uma discussão sobre a própria natureza da ficção, investigando o romance e suas possibilidades formais de apreensão e representação do mundo em determinado momento histórico. I

JOSÉ PEREIRA DE QUEIROZ - É mestrando do Programa de Teoria Literária e Literatura Comparada da USP. Ensaio apresentado à disciplina "O romance como crise e as crises do romance”, ministrada em 2017 pelos professores Sandra Guardini Teixeira Vasconcelos e Jorge Mattos Brito de Almeida. Contato: jose.pereira.queiroz@usp.br 


\section{REFERÊNCIAS BIBLIOGRÁFICAS}

ADORNo, Theodor. "A posição do narrador no romance contemporâneo". In: Notas de literatura I. Trad. de Jorge de Almeida. São Paulo: Duas Cidades, Editora 34, 2003. p. 55-63.

Benjamin, Walter. "O Narrador”. In: Magia e técnica, arte e política. Trad. de Sérgio Paulo Rouanet. São Paulo: Brasiliense, 1985. p. 197-221.

Benjamin, Walter. "Sobre alguns temas em Baudelaire". In: Obras escolhidas I/: Charles Baudelaire, um lírico no auge do capitalismo. Trad. de J. Carlos Barbosa e Hemerson Baptista. São Paulo: Brasiliense, 1989. p. 103-149.

KENNEY JR., Edwin. "The moment, 1910: Virginia Woolf, Arnold Bennett, and Turn of the Century Consciousness". Colby Library Quarterly. Waterville, n. 1, v. 13, p. 42-66, March 1977.

LUKÁCS, Georg. "O romance como epopeia burguesa". In: Arte e sociedade: escritos estéticos 1932-1967. 2. ed. Trad. de Carlos Nelson Coutinho e José Paulo Netto. Rio de Janeiro: Editora UFRJ, 2009. p. 193-243.

McKeon, Michael. "Generic transformation and social change: rethinking the rise of the novel”. In: Damrosch, Leopold. Modern essays on eighteenth-century literature. New York, Oxford: Oxford University Press, 1988. p. 159-180.

PigliA, Ricardo. "Teses sobre o conto". In: Formas breves. Trad. de José Carlos Mariani de Macedo. São Paulo: Companhia das Letras, 2004. p. 87-94.

WATT, Ian. "Realism and the novel form". In: The rise of the novel: studies on Defoe, Richardson, and Fielding. Berkeley \& Los Angeles: University of California Press, 1962. p. 9-34.

Woolf, Virginia. "An unwritten novel”. In: The complete shorter fiction of Virginia Woolf. Organização e notas de Susan Dick. San Diego: Harcourt, 1989. p. 112-121.

Woolf, Virginia. "Character in fiction". In: Selected essays. Oxford: Oxford University Press, 2008a. p. 37-54.

Woolf, Virginia. "How it strikes a contemporary". In: Selected essays. Oxford: Oxford University Press, 2008b. p. 23-30. 
Woolf, Virginia. "Modern Fiction”. In: Selected essays. Oxford: Oxford University Press, 2008c. p. 6-12.

Wootf, Virginia. “Mr. Bennett and Mrs. Brown”. In: Selected essays. Oxford: Oxford University Press, 2008d. p. 32-36.

Woolf, Virginia. "The decay of essay-writing”. In: Selected essays. Oxford: Oxford University Press, 2008e. p. 3-5. 